\title{
High Technology Industry In Israel
}

Carlos Miguel Barber Kuri, Universidad Anáhuac del Sur, Mexico

\begin{abstract}
News is frequently heard about the Arabian world regarding different types of conflicts brought about by different motives-for example, by religious, ethics, and/or cultural (as well as others). Nevertheless, when the name of Israel is spoken, an extraordinary fact must also be considered: the fact of the amazing development in high technology that its industry has presented recently.
\end{abstract}

\section{BRIEF INFORMATION ABOUT ISRAEL}

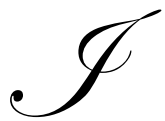

srael is located in the Middle East next to the Mediterranean Sea between Egypt and Lebanon. Historically, the territory of Israel has been a motive for conflicts, especially between Jews and Muslims. Israel as a country got her independence in 1948 after the mandate of English. The ONU divided the area between Jews and Arab territories, something that neither of which agreed. That is the reason that since its foundation to the present, Israel has not been able to reach peace, in spite of several intents.

However, in the middle of several conflicts, Israel has developed an extraordinary market economy in which the government has great participation. In spite of counting on limited natural resources, Israel has designed agricultural and industrial systems that are very efficient in the last twenty years, to the point of being auto-sufficient in several products. Now, it is interesting to observe that Israel's economy is greater than several other border countries, in spite of Israel's smaller population. Besides, Israelis have the highest level of life in the Middle East.

Fruit and vegetables, diamonds, and high technology products are some of the main exports from Israel. Additionally, the United States represents the more important source of economic and military help to Israel.

Table I: Official Data From Israel Between 2003 And 2004

\begin{tabular}{|c|c|}
\hline CAPITAL & Jerusalem \\
\hline TOTAL SURFACE & $20,770 \mathrm{~km} 2$ \\
\hline POPULATION & $6,199.008$ \\
\hline OFFICIAL LANGUAGE & Hebrew and Araba $^{\text {OFFICIAL COIN }}$ \\
\hline GROSS NATIONAL PRODUCT & Shekel $^{1}$ \\
\hline GROWING NATIONAL POPULATION & US \$19,800 \\
\hline UNEMPLOYMENT & US \$29,320 million \\
\hline EXPORTATION & US \$32,270 million \\
\hline IMPORTATION & $1.3 \%$ annual \\
\hline
\end{tabular}

\section{HIGH TECHNOLOGY INDUSTRY BACKGROUND IN ISRAEL}

Israel's high technology background began in the development of kibbutz and factories at the beginning of the twentieth century. Just before the independence in 1948, the Technion-Israel Technology Institute of Jerusalem's

\footnotetext{
${ }^{1}$ Nota: 1 shekel $=0.2317$ usd. December 2004, money exchange.
} 
Hebrew Scientific Institute, and the Weizman Scientific Institute were established, and the industry began to grow. Furthermore, after World War II, many European scientists arrived, bringing with them great amounts of talent and knowledge.

During the first years of the new Israel state, the European scientists performed great efforts for the desert to flourish. From these efforts, an important agricultural exportation industry was created. Additionally, a research and development industry was created by scientists of the Organization of Agricultural Research Volcani Center and the Agricultural Faculty of the Hebrew University. Specifically, the areas of vegetable and animal propagation as well as water and soil technology were those developed which led to the success.

The population of Israel State went through armed conflicts during the first twenty years of its existence. In view of this situation, the government came to the conclusion that they should develop their own military capacities. Because of this, research and development areas started to be geared mainly toward developing military artifacts, electronics and communication; thus finding the basis for the establishment of the first generation of Israeli high technology industries.

Agricultural research in Israel started at the end of the nineteenth century when the Israel Mikve Israel School was established. After that, the Agricultural Station was set up in Tel Aviv. In 1921 it evolved and was changed to the Organization of Agricultural Research, which nowadays is the main institution of agropecuary research and development.

The industrial investigation was started in the Dead Sea around 1930. On the other hand, technological advances had its origin in the Hebrew University of Jerusalem, as well as the Israel Technology Institute and the Daniel Sieff Research Center, and was changed to the Weizman Scientific Institute in 1949.

For its part, the medical research started just before World War I when the Hebrew Health Center was founded. With the establishment of the Microbiology Institute of the Hebrew University of Jerusalem in the mid1920 s, medical research in Israel advanced greatly. It is worth mentioning that this institute prepared the basis for the foundation of the Hadassa Medical Center, which became of great importance for Israel research purposes.

During the first part of 1970's, the Israeli Aircraft Industry built the first Israeli war plane called the Kfir (for government property). Years later, in 1980, Israel was named as the eighth country to send independently its own space satellite.

With the collapse of the Soviet Union in 1989, many Russian scientists immigrated to Israel in search of opportunities. This increased the quantity and quality of human capital for the high technology industry in Israel.

\section{ISRAELI HIGH TECHNOLOGY INDUSTRY AS A SUCCESS FACTOR}

There are several key factors to note for the success of the Israel technology industry. The most important of these factors are:

- $\quad$ High disponibility of capable human resources.

- Internationally recognized academic institutions.

- $\quad$ High development of capital risk industries.

- Foreign inversions.

- $\quad$ Active programs created by the government where research and development are the main focus, as well as several technological incubators.

- An increase in the participation of financial institutions in the country.

- $\quad$ Legislation and normative in the capital opening and adequate acquisition.

- $\quad$ Needs for advanced military technology development. 


\section{THE ROLE OF UNIVERSITIES, INSTITUTES AND RESEARCH CENTERS}

The Universities, Institutes and Research Centers have played a very important role inside the high technology industry in Israel. Among the Israelis Universities that participate in technological activities are The Hebrew University of Jerusalem, The Haifa Technion University, The Bar-Ilan University, The University of Tel Aviv, The University of Haifa, and the Ben Gurion del Negev University.

Among all these Universities, the Hadassa Medical Center and the Agricultural Faculty of The Hebrew University, Rehovot, have established several companies to register, patent, and exploit commercially the technology that they developed. Because of this, the inversion results destined to research and development made it possible for the Israelis Universities to register double the amount of patents of the American Universities and nine times higher than the Canadians.

It is important to note that the Universities in Israel work in some industrial parts of high technology. Examples of those cooperations are the Rehovot Weizman Institute and the Kiryat Industrial Park, the Jerusalem Hebrew University, and the Har Hutzvim and Malkah Industrial Parks, The Haifa Technion and the MATAM High Technology Park as well as the Tel Aviv University and the Atidim High Technology Park.

About two years ago, Israel occupied a third position in the number of per capita university graduates, just behind the U.S. and Holland. Furthermore, it has the largest number of scientists per capita in the world (135 for each 10,000 habitants), followed by the United States ( 85 for each 10,000 habitants). Israel also leads in first place in the world regarding the number of published articles and scientific essays.

It is important to mention that this country is between the first five that read more books per capita, and occupy the first place with regards to museums per habitant. This data clearly illustrates the high level of education and culture that Israelis have.

\section{ROLE OF RISK CAPITALS IN THE ISRAELI HIGH TECHNOLOGY INDUSTRY}

Risk Capital has been very important for the development of the high technology industry in Israel. Much of this capital initially served many companies and helped them during their early growth period. Nowadays there are more than seventy inversion funds that operate in Israel and are available to provide the risk capital. These help in administrative questions, and to high technology items that had recently started their operations. These funds manage more than 3,500 million dollars for the development sector.

One of the main purposes of the risk capital is to support the companies that develop the emerging technology that can be rentable. At the end of 1990's, the growth rate of risk capital increased, giving a great boost to the Israeli high technology industry.

In 1999, several multi-national companies realized the important acquisitions of Israeli companies, reaching a for-sale value of $\$ 4,500$ million dollars. This proved that the Israel high technology sector realized a major milestone in research and development, allowing for more attractive options to international companies. 
Table II: Acquisition Of Israeli Companies By Foreign Companies Between 1998 And 1999. Numbers In Million Dollars

\begin{tabular}{|c|c|c|}
\hline \multicolumn{1}{|c|}{ COMPANY } & BUYER & VALUE \\
\hline DSP Communications & Intel & 1,600 \\
\hline New Dimension & BMC & 650 \\
\hline Libit Signal & Texas Instruments & 360 \\
\hline Oshap & Sun Guard Data Systems & 210 \\
\hline Memco & Platinum & 410 \\
\hline Mirabilis & America Online & 230 \\
\hline Elbit Ultrasound & GE Medical Systems & 200 \\
\hline Teledata Telecom & ADC Telecom & 120 \\
\hline
\end{tabular}

\section{Foreign Inversion}

In the first year of Israel state, foreign interest was almost non-existent due to the constant wars, which put the country at a high investment risk.

Socialist governments believed in a solid development based in natural industry. However, at the beginning of 1970, some foreign companies began to invest in Israel. One of the companies was Motorola, established in Israel, with research and development installations in the areas of communication, equipment and semi-conductors. After that, IBM opened its installations in Haifa and a little later, Intel did the same in Haifa. IBM and Intel currently have two big plants which produce semi-conductors: one in Jerusalem and the other in Kiryat Gat.

In the 1990's, the Middle East peace process began, which reduced the risk and attracted foreign interest to Israel. Because of this, some companies such as Scitex and ECI Telecom had a great success. Their success called the attraction of foreign investors that came to Israel, creating great potential for Israel in the high technology sector.

On the other hand, there were many Israeli investors working in Silicon Valley, who decided to invest in their own country. In 1999, direct foreign inversion reached a record amount of $\$ 3,700$ million dollars. It is important to note that the main part of this investment was destined to high technology companies. Even recently, a great number of foreign companies continue to invest million of dollars in Israeli companies.

The most important of the acquisitions are:

- A share of New Dimension by American company BMC. New Dimension is dedicated to the development of software administrative systems, automatization and control. The costs of the operation was $\$ 675$ million dollars

- $\quad$ Acquisition by America Online of Mirabilis, the company that developed the message program for internet ICQ. The cost of operation was $\$ 407$ million dollars.

- $\quad$ Acquisition by Sun Guard of OSHAP, a company dedicated to the development of software for systems of vehicles and aerospace parts. Cost of the operation was $\$ 210$ million dollars.

- $\quad$ Acquisition of ORNET by Siemens. Volkswagen German Company established a joint venture of \$200 million dollars on Dead Sea Networks to extract magnesium and convert it in usable metal in automotive and spacial in ore stones. 
Table III: Recent Foreign Inversion In Israelis Companies

\begin{tabular}{|c|c|c|}
\hline FOREIGN INVERSION & ISRAELI COMPANY & YEAR \\
\hline Advanced Micro Devices & Saifun & 2002 \\
\hline Agilent & Lambda Crossing & 2001 \\
\hline AOL Time Warner & Big Band Networks & 2002 \\
\hline Applied Materials & Oramir & 2001 \\
\hline Arzon & From2 Global Solutions & 2001 \\
\hline Bausch \& Lomb & Pharmos & 2001 \\
\hline Bell Canada & Flash Networks & 2003 \\
\hline BMC Software & Aduva & 2002 \\
\hline Breach Security & Gilian Technologies & 2004 \\
\hline Cargill & Cardonet & 2002 \\
\hline Cisco Systems & $\begin{array}{l}\text { StoreAge, Riverhead Networks, Actona } \\
\text { Technologies, P-Cube }\end{array}$ & $\begin{array}{l}2001 \\
2004\end{array}$ \\
\hline Deutsche Telekom & Massage Vine, Flash Networks & $\begin{array}{l}2001 \\
2003\end{array}$ \\
\hline Eastman Kodak & Scitex Digital Printing, Algotec Systems & 2003 \\
\hline Fujitsu & Gizmoz, Saifun & $\begin{array}{l}2001 \\
2002\end{array}$ \\
\hline GE Medical Systems & InSightec & 2002 \\
\hline Hewlett-Packard & Indigo & 2002 \\
\hline Hitachi Koki & Aprion Digital & 2002 \\
\hline IBM & Aprion Digital & 2002 \\
\hline Intel & $\begin{array}{l}\text { Jungo, InfoCyclone, Bluesoft, Mobilian, Wisair, } \\
\text { Envara }\end{array}$ & $\begin{array}{l}2001 \\
2003 \\
2004\end{array}$ \\
\hline Johnson \& Johnson & Top Spin Medical, Mazor Surgical Technologies & $\begin{array}{l}2003 \\
2004\end{array}$ \\
\hline Lucent & Mobilitec & 2001 \\
\hline Merck & Solgel & 2001 \\
\hline Microsoft & Pelican Security & 2003 \\
\hline Mitsubishi Pharma & Quark Biotech & 2001 \\
\hline Nortel & Nortel Networks Israel & 2003 \\
\hline OmniCell & Medisafe & 2002 \\
\hline Polycom & Accord Networks & 2001 \\
\hline SAP & Top Tier, A2i & $\begin{array}{l}2001 \\
2004\end{array}$ \\
\hline ScanSoft & Phonetic Systems & 2004 \\
\hline Siemens & EShip-4-U & 2004 \\
\hline Texas Instruments & IXI Mobile & 2002 \\
\hline Veracicom & Always-On & 2002 \\
\hline Yahoo! & FareChase & 2004 \\
\hline
\end{tabular}




\section{ISRAEL AS A CONGLOMERATE OF HIGH TECHNOLOGY COMPANIES}

Israel has been able to consolidate some of the more important high technology industries in the whole world. In fact, it has surpassed the industrial conglomerate of the Silicon Valley in California.

The most important part of the high technology industry in Israel is located in Tel Aviv, Jerusalem and Haifa metropolitan areas. However, there are other areas where there are also important industrial activities that included Kiryat Gat and West Galilea.

The most important sector in the Israeli high technology conglomerate is the Technology of Information and Communication, better known as ICT. The industrial conglomerate of high technology is very important for the country's economy. In the year 2000, the ICT industry in Israel generated about 15,000 million dollars in exportations, representing a little more than $30 \%$ of the country's total exportation, contributing within $35 \%$ of the Gross National Product (GNP) for 2000. In 2003, Israel's ICT industry represented about $28 \%$ of Israel's total exportation and provided employment to $7 \%$ of the total workers.

These numbers show the importance of the high technology industrial conglomerate in Israel, when just 25 years prior, the economy depended mainly in the exportation of oranges and diamonds.

\section{THE IMPORTANCE OF HUMAN RESOURCES}

One of the keys of the high technology industry in Israel is the preparation and quality of the people that work in it. $20 \%$ of the laboral Israelis population has at least a university title. Furthermore, Israel constitutes the highest percentage of engineers, scientists and medical doctors in the world.

It is important to mention that a great portion of the talent of the high technology industry comes from the military forces. The best talents are recruited and put through rigorous training and capacitations in technology matters and other military functions.

In this way, young people develop knowledge and technical abilities. Besides the educational gains, experience in the solution of difficult problems, and leadership development, it is common to find that entrepreneurs of companies in high technology industries in Israel were made in the same military unit.

On the other hand, Israel labor forces have grown, thanks to the immigration of about one million people coming from the ex-Soviet Union. These immigrants have contributed their knowledge and have helped in the research and development areas, especially in the industries of software, semi-conductors, medical equipment, biotechnology, electronics and communications.

\section{GOVERNMENT PARTICIPATION}

Government plays an important role inside the industry and high technology development in Israel. It provides assistance to technology companies and gives subsidies to research and development as well as improvement and construction of industrial plants.

Industries and Commerce Ministries give million of dollars as subsidies to companies, covering between $30 \%$ and $65 \%$ of total development costs.

Furthermore, the government provides assistance through its network of more than 20 technological incubators located throughout the country.

On the other side, the industry and commerce ministries are in charge of supervising the bilateral cooperation in the research and development matters. This cooperation is mainly with the United States and Canada, the European Union and some European and Asian countries. 


\section{ISRAELI HIGH TECHNOLOGY INDUSTRIES NOWADAYS}

Since the mid-1980's, the high technology industry in Israel grew by leaps and bounds, with help mainly by the Defense Ministry. As the years passed, these industries were converted from second-rate to be on par with companies considered to be ones just behind the Silicon Valley in California.

Nowadays, Israel invests more than $2 \%$ of its GNP in research and development, being among one of the leading countries in this field. Furthermore, nowadays, there are in Israel more than 2,000 high technology companies that cover a great diversity of sectors, including:

$\begin{array}{ll}\text { - } & \text { Telecommunications } \\ \text { - } & \text { Wireless Communications } \\ \text { - } & \text { Data Communications } \\ \text { - } & \text { Sofurity Information } \\ \text { - } & \text { Medical Dispositives } \\ \text { - } & \text { Bio Technology } \\ & \text { Military Hardware and Software }\end{array}$

The majority of these companies are new and some of them have been converted to leaders at the world level in its respective area. On the other hand, some of the technology companies are among the more important and wellknown worldwide companies, which include Microsoft, IBM, Intel, Motorola, Alcatel, and $3 \mathrm{Com}$. Due to the great capacity and skills of the Israelis, these companies had installations for research and development located in Israel. It is important to mention that Intel and Motorola produced products of high technology in this nation and some transnationals had acquired Israelis companies due to quality and human talent.

Companies of high technology are established along its territory. However, the main centers are located in Atidim Industrial Park, north of Tel Aviv and Rehovot to the south. High technology Israeli companies have reached such importance that at the beginning of the century more than 80 were in the United States's stock market. These companies have represented the second most important position of foreign firms that are quoted in the American market, just behind the Canadians. Besides quoting in the United States, Israelis companies are also quoted in the most important European markets as well as in Tel Aviv.

\section{HIGH TECHNOLOGY ISRAELIS INDUSTRIES SUCCESS AFFAIRS}

Israeli high technology industry has realized important contributions. In the majority of the cases, people do not know that these inventions have been done precisely by the Israelis. However, many of them are used daily. Among the products:

- $\quad$ Motorola, Mobil Phone, that was developed within this firm

- $\quad$ Pentium MMX Technology designed by Intel, Israel

- $\quad$ Majority of Windows NT and XP Operating System created by Microsoft, Israel

- $\quad$ Voice Technology

- $\quad$ Internet ICQ Messages Program

- $\quad$ First Anti-Virus Software for PC developed in 1979

- $\quad$ The more difficult to penetrate protocol of Flight Security in the world

- The first ingerible video camera, which is so small that fit inside a pill and is used to observe the intestine from inside, that helps to diagnose cancer and other grave digestive disorders

- A new device that helps the heart to pump blood that is synchronized with the hearth mechanical work through a sophisticated sensor system 
- $\quad$ An apparatus called Clear Light, which helps the treatment of acne. This device produce a high intensity light free of ultra-violet rays that eliminates bacteria that cause acne without destroying the neighborhood coetaneous skin

- $\quad$ The air force is the fourth most important in the world, in spite of being such a small country. Just the United States, Russia and China overpass it. Furthermore, it has more than 250 F-16 airplanes which represent the second major fleet inside the United States

\section{ISRAELI HIGH TECHNOLOGY INDUSTRY AND ARMED CONFLICTS}

According to some reports elaborated by Goldman Sachs and McKinsey and Co., the high technology industry in Israel has not been affected by the reverse armed conflicts developed in the area. This is due mainly to the research and development centers that are located in its majority far away from the conflict zone.

Often, entrepreneurs from other countries are afraid to travel to Israel, due to the difficult situation. However, Israeli entrepreneurs are the ones that travel to other countries to make business deals, getting big prices for its exportation products.

It's worth mentioning that other industries such as tourism, agriculture, and construction has been gravely affected by the armed conflict. After the September $11^{\text {th }}$ terrorist attacks, tourism suffered a great fall, forcing the government to get an emergency loan of about $\$ 100$ million dollars to the hotel industry.

Other important problems that high-technology Israeli companies face is the loss of talent, as many scientists and workers of all sectors prefer to immigrate to other countries, due to the lack of security in Israel.

In spite of all the armed conflicts and the geographic difficulties, Israel has maintained as one of the world leaders in the high technology sector.

There are many countries that have many resources, however, they do not know to use it, so Israel is an example to follow. Furthermore, they are the ones that know how to change the desert into one prosperous zone and count as one of its talents the advanced technologies to change the desert in one of the most prosperous areas in the world. 